\title{
Immunomodulatory activity and phytochemical content determination of fractions of suji leaves (Dracaena angustifolia (Medik.)Roxb.)
}

\author{
1, *Handayani, N., ${ }^{2}$ Wahyuono, S., ${ }^{2}$ Hertiani, T. and ${ }^{2}$ Murwanti, R. \\ ${ }^{1}$ Department of Pharmacy, Faculty of Mathematics and Natural Sciences, Sebelas Maret University, \\ Surakarta, Indonesia \\ ${ }^{2}$ Faculty of Pharmacy, Gadjahmada University, Yogyakarta, Indonesia
}

\section{Article history:}

Received: 14 June 2019

Received in revised form: 13 July 2019

Accepted: 15 July 2019

Available Online: 9 August 2019

\section{Keywords:}

Suji leaves,

Fractions,

Immunomodulatory activity, Phytochemical content

\section{DOI:}

https://doi.org/10.26656/fr.2017.4(1).228

\begin{abstract}
Suji is a plant that has long been used as food colorant and medicinal plant in Indonesia. This study aimed to determine the immunomodulatory activity of fractions obtained from suji leaves by using in vitro phagocytic macrophage assay and also to determine the phytochemical compounds of the most active fraction. Initially, Suji dry leaves powder were macerated with $96 \%$ ethanol upon filtration, then the filtrate obtained was evaporated to dryness. The extract obtained was triturated with chloroform to give fraction soluble (F1) and insoluble fraction (F2). Then, F1 was partitioned using a mixture of hexane-methanol-water (25: 14: $1 \mathrm{v} / \mathrm{v})$ to give two layers, namely upper layer (F3) and lower layer (F4). Furthermore, the four fractions (F1, F2, F3 and F4) were tested by in vitro phagocytic macrophages method at the concentration of $10,25,50$ and $100 \mu \mathrm{g} / \mathrm{mL}$. The parameters used were the Phagocytic Index (PI) and the Phagocytic Capacity (PC). Macrophage phagocytic in vitro assay showed that fractions of the suji leaf ethanolic extract could improve the phagocytic activity of macrophages. The fraction that demonstrated the highest activity was subjected to phytochemical study by Thin Layer Chromatography (TLC). Based on the data obtained, F3 was the most active fraction, because it has the highest PC and PI values compared to other fractions or negative control. TLC test revealed that F3 contained terpenoids and flavonoids.
\end{abstract}

\section{Introduction}

Indonesia is rich in biodiversity and people have used it to maintain their health. One of the plants that have been potential to be studied is Suji (Dracaena angustifolia (Medik.)Roxb.). Suji is a plant that has long been known in Indonesia (Figure 1). The main use of suji leaves is as a food colorant because Suji leaves rich in chlorophyll pigment that produces a natural green color. As a medicinal plant, Suji has been used traditionally to treat various ailments such as headache, gonorrhea and beriberi (Heyne, 1987).

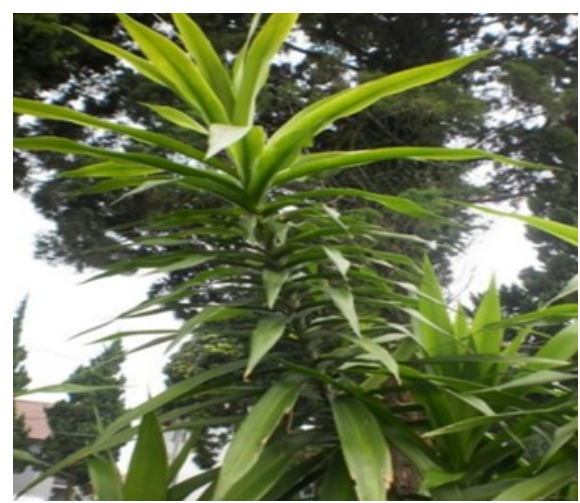

Figure 1. D.angustifolia (Priyambodo et al., 2014)
One alternative in maintaining health is immune stimulation through an immunomodulatory mechanism. Phagocytosis of macrophages is important cell defense mechanism for the fight against foreign materials and have been used as a non-specific immunological parameter for evaluating immune function (Galloway and Depledge, 2001). Immunomodulators are biological or synthetic substances that can stimulate, suppress or modulate the components of the immune system, both innate and adaptive (Agarwal and Singh, 1999). Various compounds from plants can stimulate the function of various components of the nonspecific immune system and specific immune and cytokine production so that they can be used as an adjuvant to cure various infectious diseases (Bratawidjaja and Rengganis, 2010). Potential natural immunomodulatory plants are that they have been widely use in ethnopharmacology (Yeap et al., 2011).

Previous studies have reported that Suji contains several classes of compounds such as steroid saponins, flavonoids and phenolic compounds (Tran et al., 2001; Kougan et al., 2010; Huang et al., 2013). Huang et al. 
also carried out the isolation and identification of methanol extract from $D$. angustifolia herb and 10 compounds which have been found, two of which are new steroid saponins compounds and eight other compounds. These steroid saponins are associated with Suji's activity as anti-proliferative (Tran et al., 2001), anti-inflammatory (Huang et al., 2013), anti fungi (Xu et al., 2010) and antioxidant (Priyambodo, 2014).

Many phytochemical compounds have been reported as immunomodulatory agents. Compounds such as aucubin (an iridoid), phenolics, flavonoids (Chiang et al., 2003), and saponins (Lacaille-Dubois, 2005) have been reported to possess immunomodulatory effect, and because Suji contains compounds such as steroid saponins, flavonoids and phenolic compounds, so Suji was supposed to have immunomodulatory activity.

Handayani et al. (2018), have studied about in vitro macrophage activity of ethanol extract of suji leaves. Due to the potency of ethanol extract of Suji leaves as immunomodulator, so this study is aimed to test the immunomodulatory activity of fractions of ethanol extract suji leaves and determine the phytochemical content of the most active fraction. Isolation of the compound responsible for immunodulatory activities can be recommended for further research.

\section{Materials and methods}

\subsection{Materials}

Suji leaves obtained from Sleman, Yogyakarta, Indonesia, 96\% ethanol, methanol, n-hexane, chloroform, aquadest, dimethylsulfoxide (DMSO), nbutanol, acetic acid, diethylamine, toluene, sulfuric acid, silica TLC plate F254, Balb mice males aged 2-3 months, Roswell Park Memorial Institute (RPMI) -1640 medium, sodium bicarbonate (NaHCO3) (Sigma); fetal bovine serum (FBS), penicillin, streptomycin, and amphotericin B (Gibco), phosphate-buffered saline (PBS), $3 \mu \mathrm{m}$ diameter latex beads; Giemsa paint; round slips cover; microplate 24 wells.

\subsection{Ethical clearance}

This study has been approved by the Medical and Health Research Ethics Commission of the Faculty of Medicine Gadjah Mada University, Indonesia.

\subsection{Methods}

\subsubsection{Extraction}

Specific criteria for suji leaves used were dark green colored with a length of 5 to $10 \mathrm{~cm}$ and aged 2-3 months. Suji leaves were dried in an oven at $50^{\circ} \mathrm{C}$. Dried leaves were mechanically milled to powder by the grinder. Then, dried suji leaf powder was macerated with ethanol at room temperature $\left( \pm 25^{\circ} \mathrm{C}\right)$ for $24 \mathrm{hrs}$. The results of maceration are then filtered to separate the extract from the residue. Then, the residue was macerated by ethanol for 24 hours. The liquid extract was collected then evaporated until a thick extract was produced.

\subsubsection{Fractionation}

The first fractionation stage is carried out by the trituration method. Ethanol extract is dissolved in chloroform, stirring using vortex, then separating between residue and filtrate by centrifuge. Then the residue was added chloroform again and the same process was carried out. This method was done repeatedly until the filtrate is clear. The filtrate is then called the chloroform soluble fraction (F1) and the residue is called the chloroform insoluble fraction (F2). F1 was partitioned using hexane-methanol-water solvent (28: $15: 1 \mathrm{v} / \mathrm{v})$ using a separating funnel to form two fractions, namely n-hexane fraction (F3) and methanolwater fraction (F4). Furthermore, F1, F2, F3 and F4 were carried out immunomodulatory assay using in vitro macrophage phagocytosis test method. Flow diagram of extraction and fractionation process was shown in Figure 2.

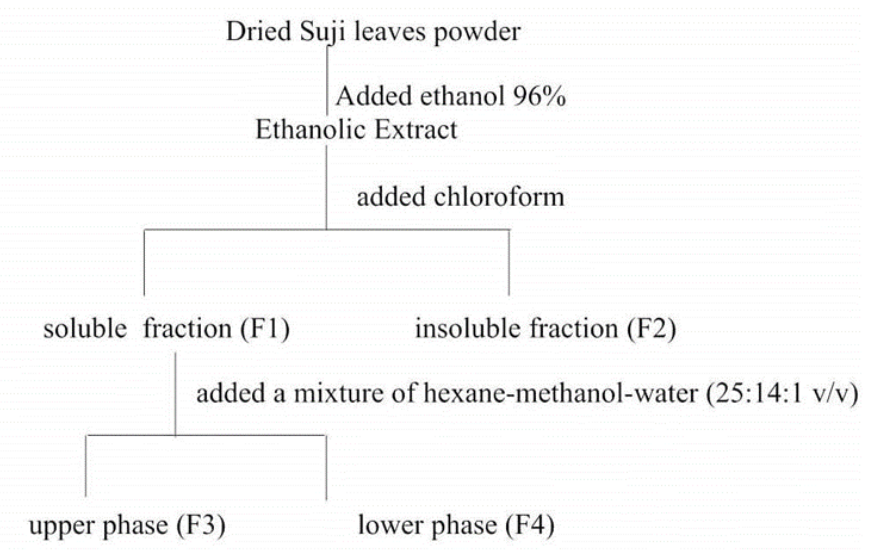

Figure 2. Extraction and fractionation step of suji leaves

\subsubsection{Isolation and cell culture of peritoneal macrophages}

Macrophages isolated from Balb/c mice males aged 2-3 months. Mice are sacrificed using chloroform, then placed on the board with the supine position. The chest to the stomach of the mice was moistened with $70 \%$ alcohol, then the abdomen sliced and opened. Peritoneal sheath first cleaned with $70 \%$ alcohol. Macrophages are isolated from the peritoneal fluid of mice by injecting 10 $\mathrm{mL}$ of RPMI 1640 cool medium into the peritoneum cavity, while rocked slowly for 5 mins so macrophages that attach to the cavity the peritoneum can be released and suspended to in the medium. Peritoneum liquid was removed and centrifuged at $1200 \mathrm{rpm}$ for 10 mins. A complete RPMI-1640 medium of $3 \mathrm{~mL}$ (containing FBS $10 \% \mathrm{v} / \mathrm{v})$ was added to pellet sediments. Cells are 
calculated by hemocytometer and then resuspension into complete RPMI medium to produce cell suspension with a density of $2.5 \times 10^{6}$ cell $/ \mathrm{mL}$. The calculated cell suspensions were cultured on plates which had been added with round coverslips. Each well was $200 \mu \mathrm{l}(5 \times$ $10^{5}$ cells). The cultures were incubated in an incubator $\left(\mathrm{CO}_{2} 5 \%\right)$ at $37^{\circ} \mathrm{C}$ for 30 mins. The cells were washed twice with RPMI and then added with complete medium ( $1 \mathrm{~mL} /$ well), and the incubation was continued for $24 \mathrm{hrs}$ (Spillsbury et al., 1995).

\subsubsection{In vitro phagocytic macrophage activity test using the latex beads method.}

After macrophage cells are cultured for $24 \mathrm{hrs}$, the media is taken using a pipette to the coverslips. Fractions with concentration $10 ; 25 ; 50$ and $100 \mu \mathrm{g} / \mathrm{mL}$, cell control, negative control (DMSO 0,0025\%) were added to the well with volume $1 \mathrm{~mL} /$ well, then incubated for 4 hrs in a $5 \% \mathrm{CO}_{2}$ incubator at $37^{\circ} \mathrm{C}$ temperature. The beads latex is suspended in PBS until the concentration is $2.5 \times 10^{7}$ latex $/ \mathrm{mL}$. A total of $200 \mu \mathrm{L}$ latex suspension was added to the well and incubated for 20 mins to give the ability of macrophages to interact with latex at $37^{\circ} \mathrm{C}$ at a $5 \% \mathrm{CO}_{2}$ incubator. The slipcover is washed with PBS three times to remove particles that are not phagocytosed and dried at room temperature and fixed with absolute methanol for $30 \mathrm{~s}$ to open macrophage membranes. After drying the coverslips were stained with Giemsa $20 \% \mathrm{~b} / \mathrm{v}$ for 30 mins. Macrophages that phagocytosed latex and latex that phagocytosed by active macrophages were calculated under a light microscope with 400X magnification (Spillsbury et al.,1995). The treatments were conducted three times.

Phagocytic activity of macrophages was assessed from the phagocytic capacity (PC) and the phagocytic index (PI) as carried out by Jensch-Junior et al. (2006). Phagocytic capacity is the number of macrophages that are active to phagocytosed of latex every 100 macrophages (\%). The phagocytic index is the amount of latex that is phagocytosed by active macrophages.

\subsection{Data analysis}

Data of phagocytic capacity and phagocytic index were analyzed using Sapphiro Wilk program to analyze normality test, followed by one-way ANOVA and Tukey HSD test at the $95 \%$ level of confidence to see the significant difference between the data. The statistical analysis uses the IBM SPSS version 23 computer program.

2.5 Phytochemical content determination using the Thin Layer Chromatography (TLC) Method

TLC analysis methods to determine phytochemical compound using Wagner and Bladt's method (Wagner and Bladt, 1996).

\subsubsection{Tannins test}

The stationary phase used was silica $\mathrm{GF}_{254}$ and nbutanol - acetic acid-water (4: 1: $5 \mathrm{v} / \mathrm{v}$ ) as the mobile phase. The presence of tannin was indicated by the formation of blue in visible light spot after the chromatogram sprayed with $\mathrm{FeCl}_{3}$ reagent.

\subsubsection{Flavonoids test}

The stationary phase used was silica $\mathrm{GF}_{254}$ and the mobile phase was n-butanol: acetic acid: water $(4: 1: 5 \mathrm{v} /$ v). After elution, the TLC plate is dried and irradiated on $\mathrm{UV}_{254}$ and $\mathrm{UV}_{366}$ lamps. The spots will appear yellow on $\mathrm{UV}_{254}$.

\subsubsection{Alkaloids test}

The stationary phase used was silica $\mathrm{GF}_{254}$ and the mobile phase was toluene: ethyl acetate: diethylamine (70: 20: $10 \mathrm{v} / \mathrm{v})$. After elution, the TLC plate was sprayed with Dragendroff reagent. When seen visually it looks brownish-orange and that was positive for alkaloid.

\subsubsection{Terpenoids test}

TLC using silica gel $\mathrm{GF}_{254}$ as the stationary phase and n-hexane - ethyl acetate $(9: 1 \mathrm{v} / \mathrm{v})$ as the mobile phase. The presence of brown color spot in the visible light after the chromatogram sprayed with cerium sulfate then heated $110^{\circ} \mathrm{C}$ showed the presence of terpenoids.

\subsubsection{Saponins test}

Using the TLC method with silica gel $\mathrm{GF}_{254}$ as the stationary phase, n-butanol -acetic acid-water (4: 1: $5 \mathrm{v}$ / v) as the mobile phase, the presence of saponins was indicated by the formation of green or blue in visible light spot after the chromatogram was sprayed with Lieberman Burchard reagent.

\section{Results and discussion}

Extraction of suji leaves was carried out by the maceration method. The filtrate was evaporated at the rotary evaporator so that it became a thick extract, obtained a yield of $9.42 \%$. Maceration is not the best strategy extraction, in any case, numerous thinks about select utilizing strategies typically because maceration could be a basic method to get the extract and suitable for unstable compounds that are degraded by the heating process. Extraction mechanism by maceration method is by means of solvents diffusing into the cell then carrying the solute out of the cell wall and mixing with the surrounding liquid. Equilibrium will occur between 
dissolved compounds in cells with solvents around them (Samuelsson, 1999). The process of fractionation from the ethanol extract of suji leaves was done by trituration and partition method. Trituration is one of the purification methods that work base on the solubility differences of the compounds in a solvent. The purpose of fractionation was to further purify or simplify the content in each fraction.

Macrophages are one of the most primitive phagocytic cells of the non-specific immune system. Phagocytic of macrophage is widely used as an immunological parameter to evaluate immune health/ function and can be analyzed by phagocytic capacity and phagocytic index parameters (Jensch-Junior et al., 2006).

Phagocytic of macrophages assay was carried out with 4 concentration levels, that were 10, 25, 50 and 100 $\mu \mathrm{g} / \mathrm{mL}$, control (-) and cell control to ensure that the media which used did not affect the phagocytosis process of macrophages. Phagocytic Index (PI) and Phagocytic Capacity (PC) were used as parameter. Activity test results based on PI and PC parameters as shown in Figure 3. Figure 4 shows that fractions have immunomodulatory activities.

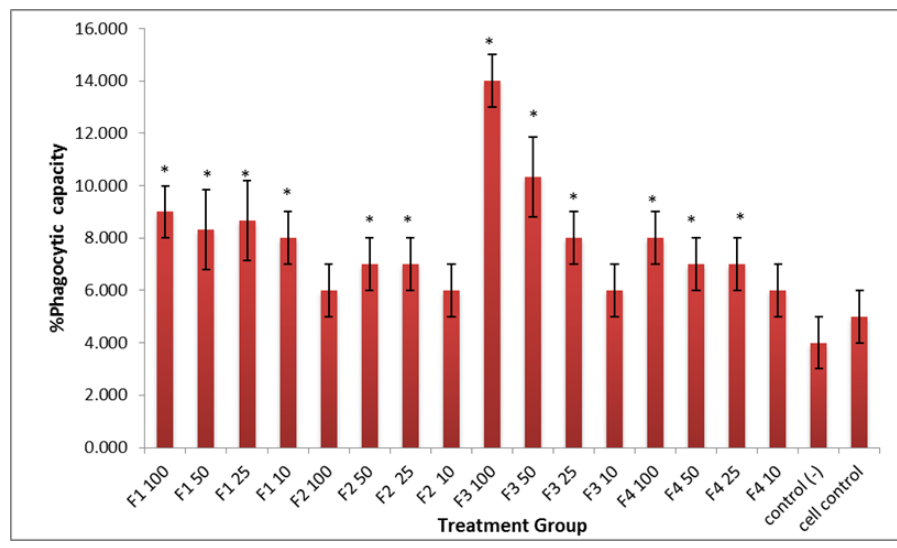

Figure 3. Phagocytic capacity value of fractions of Suji leaves. Values are expressed as mean $\pm \mathrm{SD}, \mathrm{n}=3 *^{*}$ indicated a significant difference $(p<0.05)$ between the treatment group and the control group.

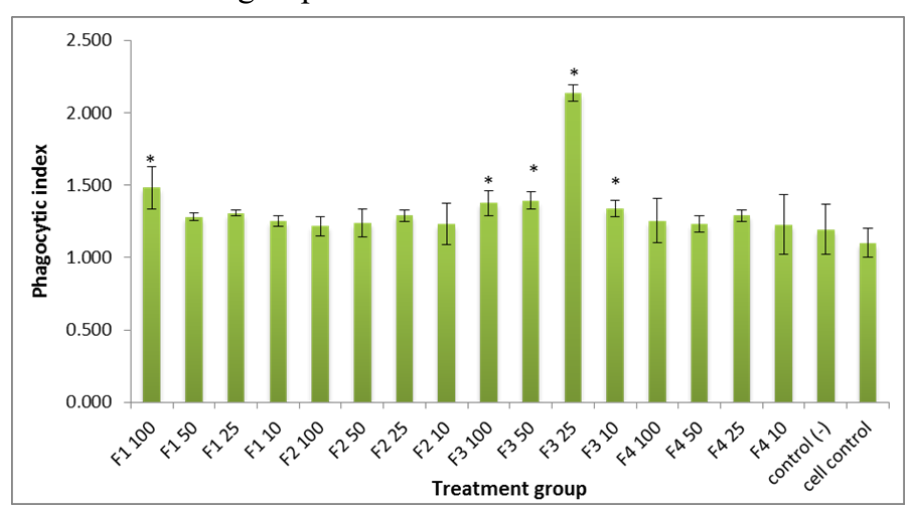

Figure 4. Phagocytic Index value of fractions of Suji leaves. Values are expressed as mean $\pm \mathrm{SD}, \mathrm{n}=3 . *$ indicated a significant difference $(\mathrm{P}<0.05)$ between the treatment group and the control group.
Statistics analysis for PC parameter values use the one-way ANOVA test followed by posthoc Tukey HSD showing that the PC value of $\mathrm{F} 1$ at all various concentrations differed significantly $(\mathrm{P}<0.05)$ with negative control and cell control, but at F2 fraction, there are only two concentrations, namely F2 25 and F2 50 (F2 at concentration 25 and $50 \mu \mathrm{g} / \mathrm{mL}$ ) which differed significantly from negative control and control cell. F3 at all various concentrations were significantly different from control, except F3 10, while for F4 all concentrations differed significantly with control, except F4 10. PI values in F1 group with 4 levels of concentration after being analyzed with oneway ANOVA showed differences between groups, while further analysis with posthoc Tukey HSD, only F1 at a concentration of $100 \mathrm{microgram} / \mathrm{ml}$ showed a significant difference with negative control and cell control. The PI values for $\mathrm{F} 2$ and $\mathrm{F} 4$ in all concentration variations showed no significant difference with control, but F3 fraction on all concentration variations showed a significant difference with the control group. The significant different value between-group treatment and control group indicates the existence of stimulation or increasing in phagocytosis activity by testing materials (Wagner and Jurcic, 1991). Need further research to find out the influence of dosage on the phagocytic activity as well as types and mechanisms of action of compounds that are responsible to the activity.

The values of PI and PC were affected by the concentration of fractions. PI and PC values of various fractions show a trend to increase to the maximum then decreases, and there is concentration optimum to the maximum value. The highest average $\mathrm{PC}$ value was seen in the F3 concentration of $100 \mu \mathrm{g} / \mathrm{mL}$ (Figure 3), while the highest average PI value was shown by the F3 concentration of $25 \mu \mathrm{g} / \mathrm{mL}$ (Figure 4). F3 fraction may contain non-polar substances which function as immunomodulators.

Determination of the phytochemical content of the F3 fraction showed the presence of terpenes and flavonoids, while the content of tannins, alkaloids and saponins showed negative results. It can be assumed that the active compounds that have immunomodulatory activity in these fractions belong to the class of terpenes and flavonoids. The role of compounds such as flavonoids and triterpenes in the immune system have been investigated by several previous researchers. Ramiro-Puig and Castle (2009) studied that polyphenols such as flavonoids, and other potential antioxidant substances could promote changes in redox-sensitive signaling pathways involved in certain genes expression that might contribute to the immunomodulatory effect. Durga et al. (2014) stated that flavonoid compounds 
such as quercetin have strong immunoregulation properties on various experimental models. Chirumbolo (2010) has also examined the role of flavonoids in modulating macrophages. The research about the effect of triterpenes pentacyclic isolated from Mangifera casturi fruit that proved to increase activity phagocytosis of macrophages was done by Sutomo et al. (2013). The results of all these studies were in accordance with Wagner and Jurcic (1991) that the polysaccharide compounds, terpenoids, alkaloids, phenolics, flavonoids, isoflavonoids and triterpenes are useful as anticancer and immunomodulatory agents.

\section{Conclusion}

Macrophage phagocytic in vitro assay showed that fractions of the suji leaf ethanolic extract could improve the phagocytic activity of macrophages. F3 is the most active fraction because it has the highest PC and PI values compared to other fractions or negative control. Based on TLC analysis, it was revealed that F3 contains terpenes and flavonoids.

\section{Conflict of interests}

Authors declare no conflict of interest.

\section{Acknowledgements}

We are grateful to the Ministry of Research and Directorate Higher Education, the Republic of Indonesia for funding this research by Doctoral Dissertation Grant Program with the contract number of 098/SP2H/LT/DRPM/IV/2017.

\section{References}

Agarwal, S.S. and Singh, V.K. (1999). Immunomodulators: A review of Studies on Indian Medicinal Plants and Synthetic Peptides. PINSAB65, 3(4), 179-204.

Bratawidjaja, K.G. and Rengganis, I. (2010). Imunologi Dasar. $9^{\text {th }}$ ed. Jakarta : Fakultas Kedokteran Universitas Indonesia. [In Bahasa Indonesia].

Chiang, L.C., Chiang, M.Y. and Chang, C.L. (2003). Immunomodulatory Activities of Flavonoids, Monoterpenoids, Triterpenoids, Iridoidglycosides and Phenolic Compounds of Plantago Species. Planta Medica, 69(7), 600-604. https:// doi.org/10.1055/s-2003-41113

Chirumbolo, S. (2010). The Role of quercetin, flavonols, and flavones in modulating inflammatory cell function. Inflammation and Allergy - Drug targets, $\quad 9(4), \quad 263-285 . \quad \mathrm{https}: / /$ doi.org/10.2174/187152810793358741
Durga, M., Nathiya, S. and Devasena, T. (2014). Immunomodulatory and antioxidant actions of dietary flavonoids. International Journal of Pharmacy and Pharmaceutical Sciences, 6(2), 5056.

Galloway, T.S. and Depledge, M.H. (2001). Immunotoxicity in Invertebrates: Measurement and Ecotoxicological Relevance. Ecotoxicology, 10(1), 5 -23. https://doi.org/10.1023/A:1008939520263

Handayani, N., Wahyuono, S., Hertiani, T. and Murwanti, R. (2018). Uji fagositosis makrofag ekstrak etanol daun Suji (Dracaena angustifolia (Medik.)Roxb. ) secara in vitro. Pharmacy Medical Journal, 1(1), 26-32. [In Bahasa Indonesia]. https://doi.org/10.35799/ pmj.1.1.2018.19648

Heyne, K. (1987). Tumbuhan Berguna Indonesia, $1^{\text {th }}$ ed. Terjemahan Badan Litbang Kehutanan. Jakarta: Departemen Kehutanan [In Bahasa Indonesia].

Huang, H.C., Lin, M.K., Hwang, S.Y., Hwang, L.T., Kuo, Y.H. and Chang, C. (2013). Two Antiinflammatory Steroidal Saponins from D.angustifolia. Molecules, 18(8), 8752-8763. https:// doi.org/10.3390/molecules18088752

Jensch-Junior, B.E., Pressinotil, N., Borges, J.C.S. and Silva, C.D. (2006). Characterization of Macrophage Phagocytosis of the Tropical Fish Prochilodus srofa. Aquaculture, 251(2-4), 509-515. https:// doi.org/10.1016/j.aquaculture.2005.05.042

Kougan, G.B., Miyamoto, T., Tanaka, C., Paululat, T., Mirjolet, J.F., Duchamp, O., Sondengam, B.L. and Lacaille-Dubois, M.A. (2010). Steroidal saponins from two species of Dracaena. Journal of Natural Products, 73(7), 1266-1270. https://doi.org/10.1021/ np100153m

Lacaille-Dubois, M.A. (2005). Bioactive Saponins with Cancer Related and Immunomodulatory Activity: Recent Developments. Studies in Natural Products Chemistry, 32(Part L), 209-246. https:// doi.org/10.1016/S1572-5995(05)80057-2

Priyambodo, W.J., Sudarsono. and Rohman, A. (2014). The Antiradical Activity of Insoluble Water Suji (Pleomele angustifolia N.E. Brown) Leaf Extract and Its Application as Natural Colorant in Bread Product. Journal of Food and Pharmaceutical Sciences, 2(2), 52-56.

Ramiro-Puig, E. and Castell, M. (2009). Cocoa: Antioxidant and Immunomodulator. British Journal of Nutrition, 101(7), 931-940. https:// doi.org/10.1017/S0007114508169896

Samuelsson, G.(1999). Drugs of natural origin. $4^{\text {th }} \mathrm{Ed}$. Sweden: Swedish Pharmaceutical Press. 
Spillsbury, K., Omara, M.A., Wu, W.M., Rowe, P.B. and Takayama, Y. (1995). Isolation of a Novel Macrophage-Specific Gene by Differential cDNA Analysis. Blood, 85, 1620-1629.

Sutomo, Wahyuono, S., Rianto, S. and Setyowati, E.P. (2013). Isolation and identification of active compound of n-hexane fraction from kasturi (Mangifera casturi Konsterm.) against the antioxidant and immunomodulatory activity. Journal of Biological Sciences, 13(7), 596-604. https:// doi.org/10.3923/jbs.2013.596.604

Tran, Q.L., Tezuka, Y., Banskota, A.H., Tran, Q.K., Saiki, I. and Kadota, S. (2001). New spirostanol steroids and steroidal saponins from roots and rhizomes of D. angustifolia and their antiproliferative activity. Journal of Natural Products, 64(9), 1127-1132. https:// doi.org/10.1021/np0100385

Wagner, H. and Jurcic, K. (1991). Assay for immunomodulation and effect on mediators of inflammation In Dey, P.M. and Harborne, J.B. (Eds.). Methods in Plants Biochemistry: assay for bioactivity. London: Academic Press.

Wagner, H. and Bladt, S. (1996). Plant Drug Analysis, A thin layer chromatography atlas. Berlin Heidelberg: Springer.

Xu, M., Zhang, Y.J., Li, X.C., Jacob, M.R. and Yang, C.R. (2010). Steroidal saponins from fresh stems of $D$. angustifolia. Journal of Natural Products, 73(9), 1524-1528. https://doi.org/10.1021/np100351p

Yeap, S.K., Rahman, M.B.A., Alitheen, N.B., Ho, W.Y., Omar A.R. and Beh, B.K. (2011). Evaluation of immunomodulatory effect: selection of the correct targets for immunostimulation study. American Journal of Immunology, 7(2), 17-23. https:// doi.org/10.3844/ajisp.2011.17.23 